\title{
Evaluation of a mitigation proposal on the final disposal of lead-based batteries and its environmental impact
}

INGENIERÍA INDUSTRIAL

\section{Evaluación de una propuesta de mitigación del impacto ambiental en la disposición final de las baterías a base de plomo para automóviles}

\author{
Sylvia M. Villarreal-Archila ${ }^{1 \S}$, Cristiam Serrano-Figueroa ${ }^{1}$, Daniela K. Quiroga-Rojas ${ }^{1(\mathbb{D}}$ \\ ${ }^{1}$ Manuela Beltrán University, Faculty of Engineering, Industrial Engineering School, Bucaramanga, \\ Colombia \\ §sylvia.villareal@docentes.umb.edu.co, cristiam.figueroa@academia.umb.edu.co,
} daniela.quiroga@academia.umb.edu.co

Recibido: 03 de diciembre de 2019 - Aceptado: 04 de septiembre de 2020

\begin{abstract}
Based on the design of a proposal to mitigate the environmental impact generated by lead-based batteries for automobiles, an environmental impact assessment was carried out using the Vicente Conesa method, where it was discovered that the most negative impacts on the environment are those produced by the treatment of the electrolyte and the lead and acid recovery. Subsequently, a comparison was made between the current process and the ideal one, obtaining a model developed in the FlexSim software. After executing the relevant simulations for the study, it was evident that performing the proposed model represents an increase in the duration of the final disposal stage of the batteries, the previous as a result of the implementation of stages associated with the treatment of recycled batteries remnants, such as plastic, acid, and lead. However, standardizing the proposed model would suppose significant mitigation in the different environmental impacts generated by said process, managing to avoid legal sanctions by environmental authorities.
\end{abstract}

Keywords: Batteries, Contamination, Environmental Impact, Mitigation, Pollutant.

\section{Resumen}

A partir diseño de una propuesta de mitigación del impacto ambiental generado por las baterías a base de plomo para automóviles. Se realizó la evaluación del impacto ambiental de la disposición de baterías a través del método Vicente Conesa, donde se encontró que los mayores impactos ambientales son los producidos por el tratamiento del electrolito, recuperación del plástico y plomo, entonces, se realizó la comparación del proceso actual y se propuso un modelo ideal mediante una simulación en FlexSim, y se determinó que el tiempo del proceso ideal propuesto 
representa un aumento en el tiempo total en la disposición final de las baterías ácido-plomo debido a la adición de etapas para el tratamiento del ácido, plomo y plástico, pero que supone una mitigación significativa de los impactos ambientales causados por este procedimiento y con ello la evasión de sanciones por parte de autoridades ambientales.

Palabras clave: Baterías, Impacto ambiental, Plomo, Rectificación, Contaminante.

\section{Introduction}

Batteries rectification is a process that must be carried out in an appropriate area since its chemical compounds negatively affect the environment with the acidification of waters by sulfuric acid pouring. Moreover, it produces acid rain, which is when vapors dissolved into the water contained in the air fall to the ground, modifying the chemical characteristics of ecosystems by acidifying the soil and affecting living things ${ }^{(1)}$. In the case of Bucaramanga, the rectification of lead-acid batteries is carried out, mostly informally, using handcrafted or poorly standardized methods under precarious conditions regarding health, hygiene, and environment. Workshops dedicated to this practice are mainly divided into two areas: the urban-industrial sector, on the main roads of the city; and the other one near river banks such as Río de Oro in Girón, where the waste generated by the activity is a source of soil and water pollution, that ends up damaging the river's flow and severely affecting the organisms that inhabit it.

Considering that lead-batteries are a priority need for vehicles because of their energy supplying function and the guarantee they offer regarding mobility and displacement; researchers used the Vicente Conesa method to prioritize the most affected environmental factors concerning the final disposal of the batteries. The latter reduces the high levels of contamination generated by the lead batteries and establishes essential procedures to include in the ideal's standardization process that people should follow when trying to execute such activity, aimed at informal workshops by analyzing time frames and machines and tools.

The main results are presented as follows:

Section two includes the theoretical references necessary for the formulation and execution of the research. Section three describes the methodology implemented. In section four, the results are presented, while in section five, the reader will find the discussion and analysis of those findings. Finally, section six presents conclusions.

\section{Literature Review}

\subsection{Environmental impact assessment}

The environmental impact assessment (EIA) is carried out to discover and analyze the causes and effects of the activities that work, and projects generated, from identification, prediction, quantification to their final assessment. EIA can be either positive or negative and can be classified according to its effect over time as irreversible, temporary, reversible, and persistent. Various methodologies would help to determine such effects. However, there is no specific method that satisfies the diversity of environmental aspects that one might like to research. Therefore, it is necessary to examine different procedures according to the requirements that each study or project presents. Table 1 shows the methodologies consulted:

Table 1. Environment Impact Assessment Methods

\begin{tabular}{lc}
\hline Methodology & Description \\
\hline CONESA & The Vicente Conesa matrix is one of the \\
\hline
\end{tabular}




\begin{tabular}{ll}
\hline Method & most common and used methods, and it \\
is based on cause-effect matrices. \\
A simple verification system that allows \\
organizing both the assessment process \\
and the impact monitoring process, so \\
that not to miss any of the factors. Its \\
objective is to predict possible outcomes \\
for the actions that are carried out. \\
A qualitative method that identifies and \\
analyzes the interactions that emerge \\
between the project and the \\
environment. This matrix, for each \\
action, estimates all the environmental \\
factors that can be eloquently affected. \\
Qualitatively assesses environmental \\
problems, so that the production chain is \\
environmentally friendly in its entirety. \\
It is based on a matrix that vertically \\
analyzes the product life cycle and \\
horizontally its effects. These problems \\
are classified into the materials cycle \\
(input/output), energy use \\
(input/output), and waste (output). \\
It is a quantitative method that allows \\
the development of a methodical EIA \\
from a project or activities carried out \\
within it, achieving medium and long- \\
term planning with the least possible \\
impact.
\end{tabular}

\subsection{Operation and composition of the lead- acid batteries}

A lead storage battery, also known as a lead-acid battery, is a common type of battery used in conventional vehicles as a starter battery, or as a traction battery (EVB: Electric-Vehicle Battery) for electric motors. Approximately $85 \%$ of the total global consumption for lead refining is for the manufacturing of lead-acid batteries, a demand that can be positively addressed mainly because of recycled lead. However, that recycling process is a significant cause of environmental pollution and human exposure ${ }^{(2)}$. Vehicle batteries contain two chemicals that help spread water and soil pollution, making them very disruptive for the environment and human health. These substances are sulfuric acid, which is corrosive, and lead, which is a toxic agent that enters the body by inhalation or ingestion, lodging in the organs, causing burns or skin and eye irritations. In the medium-long term, it can cause multiple diseases such as anemia, central nervous, bones and muscular systems conditions, migraine, fatigue, sleep disorder, abdominal pain, decreased appetite, and, in severe cases, kidney damage and even death ${ }^{(3)}$. The lead contained in the batteries is a resource necessary for its operation. However, it runs out over time, which is why battery recycling becomes a necessity, and the commercialization of nonoperating batteries increases, allowing the settling of informal areas dedicated to this practice, and, at the same time, creating a handling issue ${ }^{(4)}$. Therefore, battery recycling is considered one of the most harmful activities for the environment ${ }^{(5)}$.

The recycling process begins by collecting the discarded batteries at collection points and junkyards in the city. They are then stored in workshops until the disassembly procedure begins. Subsequently, the batteries are shredded in a crusher to obtain the three main recycling elements: lead, plastic, and acid.

Lead components such as iron, carbon, and sodium carbonate are melted and reduced in the furnace. At this point, lead no longer has unwanted impurities, and workers have to decide whether to empty the lead components in molds to obtain solid blocks of the material, or to mix them with chemical elements to produce lead alloys in refining boilers, using some alloy elements such as tin, selenium, antimony or arsenic.

Besides, workers inspect the plastic to determine its quality and discover its impurities, to decide whether to dispose of it, burn it, or recycle it. In the second case, some procedures must be executed to transform the components into granules or pellets that will later be melted in the manufacture of new products. 
Finally, the last removable component of leadacid batteries is acid, which is reused in new batteries if it is in an acceptable state or gets neutralized to be released into the sewer system.

There are some risks linked to this practice because of some main components that batteries have, especially for the health of lead-exposed people. Lead represents one of the leading causes of occupational diseases and even affects the well-being of communities surrounding battery collection and rectification plant areas ${ }^{(6)}$. It also affects many organs, systems, and physiological processes, such as the kidneys, the cardiovascular and reproductive system, and, in the worst cases, it would probably affect the central nervous system development (CNS) ${ }^{(7)}$. Moreover, some environmental impacts are caused by sulfuric acid, lead, and plastic. They will get briefly described below.

When sulfuric acid vapors are mixed with water contained in the rain, a very disruptive form of precipitation gets created, affecting ecosystems and vegetation, acting as corrosive or annihilating some species ${ }^{(7)}$. Also, there is a high-risk that surface water could get contaminated, which represents a threat to aquatic ecosystems ${ }^{(8)}$. Furthermore, lead adheres firmly to soil particles, stays in its upper layer, contaminates it, and remains for many years ${ }^{(9)}$, affecting soil living organisms, such as fungi, bacteria, ants, larvae, and earthworms ${ }^{(10)}$. The previous aspects lead to alterations in the soil composition, which loses vital nutrients for plants, such as calcium, and allows toxic metals mobilization that might affect the surrounding water currents ${ }^{(11)}$.

The air is affected by the combustion of the plastic casings of the batteries, which might have lead remnants and sulfuric acid, thus generating toxic smoke. Additionally, lead has the ease of floating in the air when the particles are tiny.

\section{Methodology}

\subsection{Research method}

The objective of this research paper was to design and evaluate a mitigation proposal on the environmental impact generated by lead-based batteries for automobiles by analyzing the final stage of the batteries' life cycle to improve the living conditions of those involved directly or indirectly with such practice. The project was conducted by assigning a projective scope with a mixed-method approach, which allows the researcher to understand by the observation process how the batteries' restoration practice affects and threatens the environment. This research also presents a review of the environmental impact and its main characteristics.

The target population was the manufacturing companies and the rectifier workshops of leadacid batteries in Bucaramanga, Santander, which were identified by exploring Bucaramanga's Cámara de Comercio through the "Compite 360" platform, obtaining seven results from the "CIIU: 2720" code and 53 results from the "3314" code. The sample was established through the convenience sampling technique due to the ease of access, the availability of people, and the public and previous knowledge from some practices that were carried out by these frequent workshops in other similar ones in the time interval of the research development. The sample was composed of five workshops dedicated to the rectification, maintenance, and manufacturing of lead-based batteries for vehicles.

\subsection{Methodological design}

In this section, three stages were defined to meet the objective of the research. Those were: The environmental impact assessment, the mitigation proposal, and a final evaluation to test the proposal's functionality. 
In the first stage, the foundations of the current process were established through a literature review, some direct observations of the process, and a few interviews. The Vicente Conesa method was used due to the three cause-effect matrices that it provides, the qualitative assessment, the impact matrix, and the priority matrix.

Researchers evaluated ten parameters to get numerical results from a range of 0 to 100 to determine the relevance of the impacts in each stage of the recovery cycle of lead-acid batteries. The impact relevance was determined depending on the effect, which could be compatible, moderate, critical, or severe. In the second stage, the environmental and social impact mitigation proposal was designed and later synthesized in an explanatory booklet that included the most relevant aspects of the impact assessment and the essential elements that could be developed on a day-to-day basis. Finally, to assess the operation of the proposal, the simulation of the process was carried out, based on data analysis on quantitative variables in the FlexSim software, where the input and output variables of the process were included.

\section{Results}

\subsection{Current state assessment}

The recyclability of lead-acid batteries is a process carried out in different stages, and it is divided into two categories: previous recycling and recycling ${ }^{(10)}$. The result is the collection of lead, plastic, and other remnants that are used in the production of new batteries or are used separately as a raw material in the manufacturing of different items such as bearings, bullets, and weights or liquid fertilizers when it comes to lead ${ }^{(12)}$.

It was necessary to visit the workshops with a concrete proposal to carry out the diagnosis stage. By doing so, it was possible to accomplish the observation process, obtaining photographic evidence, and measuring the time frames associated with the activities studied. Figure 1 shows the evidence.

To proceed with the assessment stage, researchers designed an EIA matrix divided into 16 activities to assess the five stages of the battery recovery cycle. For each item, six environmental aspects (air, water, soil, flora, fauna, and socioeconomic) were weighted based on the importance of qualification parameters defined by the methodology. Table 2 shows the assessment on the weighting stage (the other stages were assessed in the same way).

The reception stage consists of collecting and transporting the batteries. In the qualified aspects and impacts, it was possible to obtain signs of positive impacts because pollution and what it entails are being counteracted, hierarchically

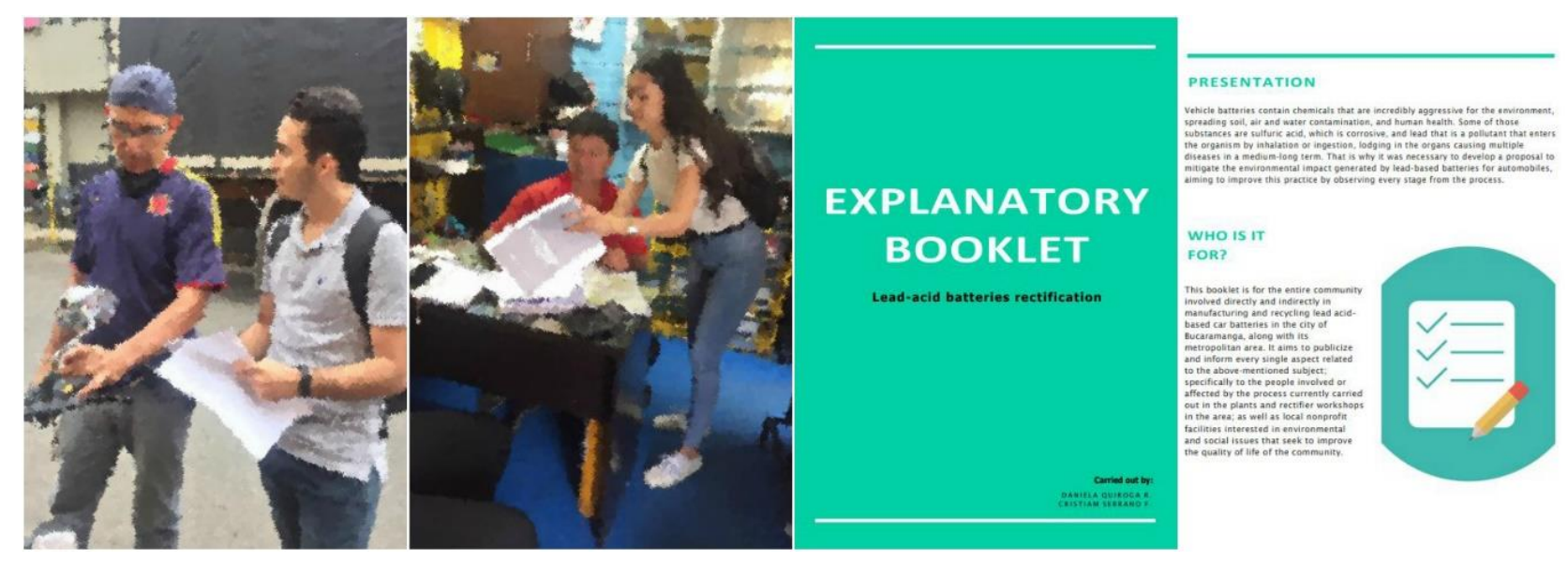

Figure 1. Proposal socialization 
organizing the following factors: air, soil, socioeconomic, and water.

The decomposition stage consists of shredding and gravity separation by sieving. The potential impacts from the previous activities were classified as unfavorable, as both processes produce pollutants or splinters that affect the air, water, and soil, as well as flora and fauna on a secondary level.

The melting stage consists of four activities: lead smelting, removal of impurities, alloying, and mold casting. The potential impacts of the previous activities were classified as unfavorable, as all of them produce small particles that can find their way to the environment and severely affect it. When analyzing the results, the most affected factors were the following, from the highest to the lowest: air, water, the socioeconomic factor, and subsequently, the soil, and flora and fauna.

The fourth stage of plastic treatment consists of washing, crushing or shredding, casting, granule extracting, incineration, disposal, and plastic recovery. The results show a negative impact since, when carrying out the plastic treatment, whether, in washing, handling, or waste stages, the lead and acid are always incorporated into the water and later discarded into the sewer system. Plus, when plastic is getting melted at this stage, the crushing machine produces carbon dioxide, which is another pollutant. The above situations significantly affect the following environmental factors, ordered from the highest to the lowest: air, water, socioeconomic, soil, flora, and fauna. On the other hand, it was possible to get a favorable result from this stage when the granules used to make new plastic products or new casings for other batteries were obtained $^{(11)}$.

The fifth stage is for the electrolyte treatment, which consists of alkalinity neutralization and sewer release. Results from this stage follow the same pattern as before, showing a negative impact due to the contamination generated by liquid spills in the sewer systems that will eventually rejoin water currents. Alkalinity neutralization can mitigate the previous impact if carried out correctly. Liquid spills in the sewer system mainly affect water sources and soil and, secondarily, socioeconomic factors, flora, and fauna.

Table 2. Environmental impact assessment of lead-acid batteries recycling

\begin{tabular}{|c|c|c|c|c|c|c|c|c|c|c|c|c|c|c|c|c|c|}
\hline \multirow[b]{2}{*}{ 离 } & \multicolumn{17}{|c|}{ Life cycle analysis of lead-acid batteries. VICENTE CONESA Method } \\
\hline & 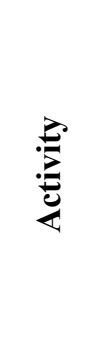 & 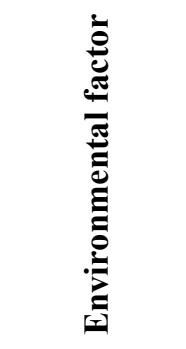 & 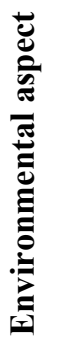 & 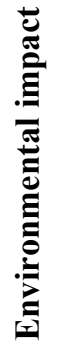 & 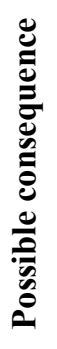 & 辛 & 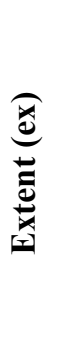 & 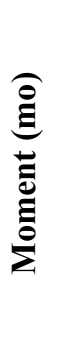 & 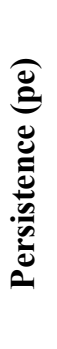 & 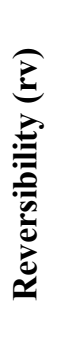 & 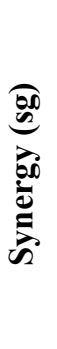 & 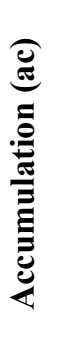 & $\underset{\underbrace{}}{\stackrel{e}{e}}$ & 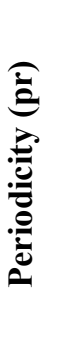 & 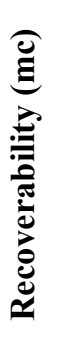 & 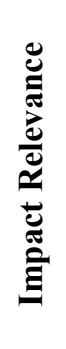 & \\
\hline \multirow{6}{*}{ 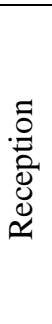 } & \multirow{6}{*}{ 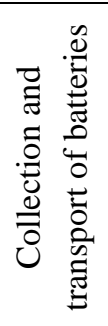 } & Air & & $\mathrm{X}$ & + & 8 & 8 & 4 & 2 & 4 & 4 & 4 & 4 & 4 & 4 & 70 & Critical \\
\hline & & Water & & $\mathrm{X}$ & + & 2 & 4 & 2 & 2 & 4 & 2 & 1 & 4 & 2 & 4 & 35 & \multirow{2}{*}{ Moderate } \\
\hline & & Soil & & $X$ & + & 4 & 2 & 4 & 2 & 4 & 4 & 4 & 4 & 2 & 2 & 42 & \\
\hline & & Flora & $\mathrm{X}$ & & + & 2 & 2 & 2 & 1 & 2 & 2 & 1 & 1 & 2 & 2 & 23 & \multirow{2}{*}{ Compatible } \\
\hline & & Fauna & $\mathrm{X}$ & & + & 2 & 2 & 2 & 1 & 2 & 2 & 1 & 1 & 2 & 2 & 23 & \\
\hline & & $\begin{array}{l}\text { Socioecono } \\
\text { mic }\end{array}$ & & $\mathrm{X}$ & + & 4 & 2 & 2 & 1 & 1 & 4 & 4 & 4 & 4 & 1 & 37 & Moderate \\
\hline
\end{tabular}




\subsection{Mitigation proposal simulation}

The simulation process was carried out in the FlexSim software, representing the appropriate rectification process of lead-acid batteries. The simulation consisted of three stages, which are defined as follows: the first one corresponds to the modeling of the lead-acid battery recycling process based on the collected information; the second one validates the proper operation of the drawn model. The last stage refers to the discussion of the results obtained from the analysis of output data.

Figure 2 shows a current conceptual model that researchers developed from information obtained through discussions and factual evidence gathered from the workshop visits, which allowed the record of the sequence, the steps, and the time frames that these workshops have when carrying out the recycling process. The previous information was later modeled into the software.

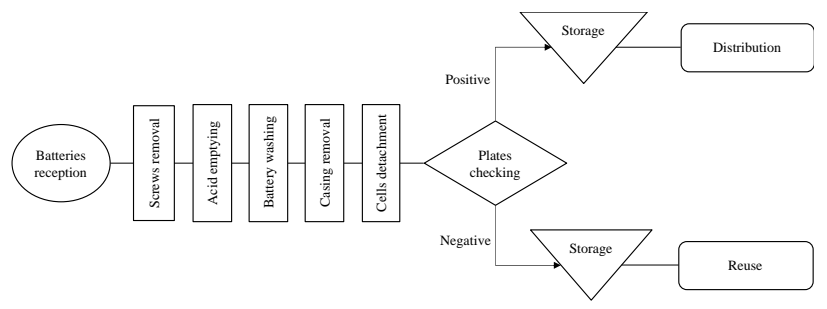

Figure 2. Conceptual model of the current-informal process of battery recycling

On the other hand, the following hypothesis was presented: The duration of the proposed battery recycling process will increase compared to the current one. However, the environmental impact will decrease due to the improvements made in the process.

Researchers proceeded to validate the data obtained in the videos through the ExpertFit tool to establish the types of distribution that the battery recycling threads follow, carrying out Goodness and Fit tests on three variables that presented the most constant changes in time so to have reliability in the average time of each of the processes that were going to be simulated in the software.

The emptying time behaves with a tendency towards a Johnson distribution. Researchers also performed a Chi-Square test, which did not reject the hypothesis with results ranging from $75 \%$ to $99 \%$, as shown in Figure 3.

On the other hand, the washing time behaves with a tendency towards a Beta distribution. A Chi-Square test that was performed did not reject the hypothesis with results ranging from $75 \%$ to 99\%, as shown in Figure 4.

Times frames for cell detachment and plate separation have a behavior with a tendency towards a Johnson distribution. A Chi-Square test that was performed did not reject the hypothesis with results ranging from $75 \%$ to 99\%, as shown in Figure 5.

Once the above has been carried out, researchers designed simulation models for the current and the proposed processes. The data validation was applied in both models according to their distribution in the tests when representing the existing steps in the waste disposal process of used batteries.

Figure 6 shows the model of the current process with its respective flow. It has some stages that are carried out informally in the final disposal step of lead-based batteries. For software interface reasons, each phase was represented as a machine. 
Equal-Width Chi-Square Test with Model 1 - Johnson SB

$\begin{array}{ll}\text { Upper endpoint of first interval } & 13.85 \\ \text { Interval width } & 0.85 \\ \text { Number of intervals (grouped/original) } & 8 / 8 \\ \text { Number of intervals with fewer than } & \\ \quad \text { five expected observations per interval } & 8 \\ \text { Test statistic } & 2.06075\end{array}$

Warning: The test may not be statistically valid because a method other than maximum likelihood was used to estimate parameters.

\begin{tabular}{|c|c|c|c|c|c|c|}
\hline \multirow{2}{*}{$\begin{array}{l}\text { Degrees } \\
\text { of Freedom }\end{array}$} & Observed Level & \multicolumn{5}{|c|}{ Critical Values for Level of Significance (alpha) } \\
of Significance & 0.25 & 0.15 & 0.10 & 0.05 & 0.01 \\
\hline \hline 3 & 0.560 & 4.108 & 5.317 & 6.251 & 7.815 & 11.345 \\
\hline \hline 7 & 0.956 & 9.037 & 10.748 & 12.017 & 14.067 & 18.475 \\
\hline & Reject? & No & \multicolumn{5}{|c|}{} \\
\cline { 5 - 8 }
\end{tabular}

Figure 3. Affinity validation between Johnson distribution and emptying process time frames

Equal-Width Chi-Square Test with Model 1 - Beta

\begin{tabular}{ll} 
Upper endpoint of first interval & 22.11 \\
Interval width & 0.71 \\
\hline Number of intervals (grouped/original) & $8 / 8$ \\
Number of intervals with fewer than & \\
five expected observations per interval & 8 \\
Test statistic & 1.45203
\end{tabular}

Waming: The test may not be statistically valid because a method other than maximum likelihood was used to estimate parameters.

\begin{tabular}{|c|c|c|c|c|c|c|}
\hline \multirow{2}{*}{$\begin{array}{c}\text { Degrees } \\
\text { of Freedom }\end{array}$} & Observed Level & \multicolumn{5}{|c|}{ Critical Values for Level of Significance (alpha) } \\
of Significance & 0.25 & 0.15 & 0.10 & 0.05 & 0.01 \\
\hline \hline 3 & 0.693 & 4.108 & 5.317 & 6.251 & 7.815 & 11.345 \\
\hline \hline 7 & 0.984 & 9.037 & 10.748 & 12.017 & 14.067 & 18.475 \\
\hline
\end{tabular}

Figure 4. Affinity validation between Beta distribution and washing process time frames

\begin{tabular}{|c|c|c|c|c|c|c|}
\hline \multicolumn{7}{|c|}{ Equal-Width Chi-Square Test with Model 1 - Johnson SB } \\
\hline \multicolumn{3}{|c|}{$\begin{array}{l}\text { Upper endpoint of first interval } \\
\text { Interval width } \\
\text { Number of intervals (grouped/original) } \\
\text { Number of intervals with fewer than } \\
\text { five expected observations per interval } \\
\text { Test statistic }\end{array}$} & \multicolumn{4}{|l|}{$\begin{array}{l}8 \\
2.10110\end{array}$} \\
\hline \multicolumn{7}{|c|}{ ther than maximum likelihood was used to estimate parameters. } \\
\hline \multirow{2}{*}{$\begin{array}{l}\text { Degrees } \\
\text { of Freedom }\end{array}$} & \multirow{2}{*}{$\begin{array}{l}\text { Observed Level } \\
\text { of Significance }\end{array}$} & \multicolumn{5}{|c|}{ Critical Values for Level of Significance (alpha) } \\
\hline & & 0.25 & 0.15 & 0.10 & 0.05 & 0.01 \\
\hline 3 & 0.552 & 4.108 & $\mathbf{5 . 3 1 7}$ & 6.251 & 7.815 & 11.345 \\
\hline \multirow[t]{2}{*}{7} & 0.954 & 9.037 & 10.748 & 12.017 & 14.067 & 18.475 \\
\hline & Reject? & \multicolumn{5}{|l|}{ No } \\
\hline
\end{tabular}

Figure 5. Affinity validation between Johnson distribution and the time frames from the cell detachment and plates separation processes 


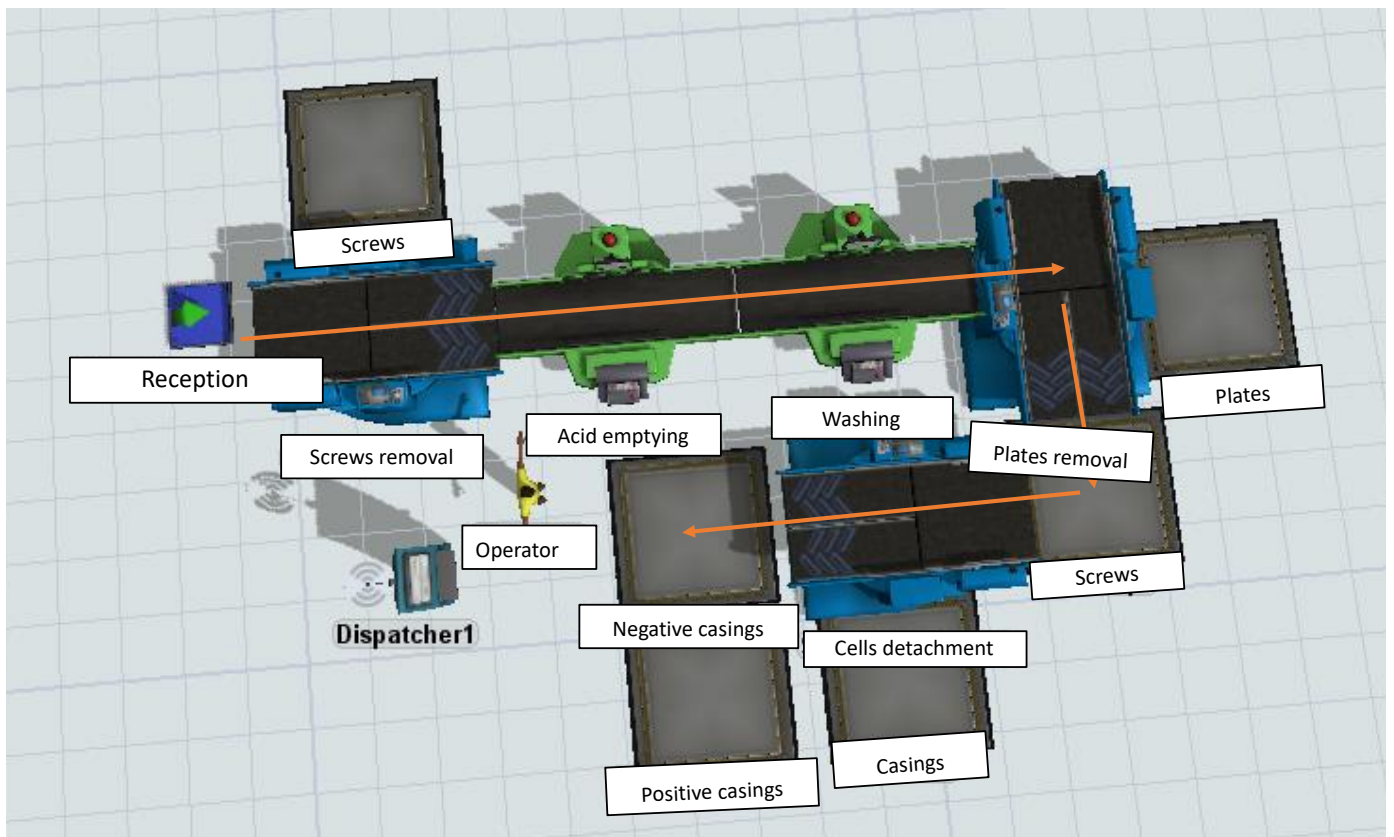

Figure 6. Model for the current final disposal process of lead-acid batteries

Figure 7 shows the model of the ideal and adequate process with its respective flow. It has the different stages that should be carried out in the final disposal step of lead-based batteries. For software interface reasons, each phase was represented as a machine.

\subsection{Models comparison}

The designed and later proposed models went through some validations necessary to interpret and analyze the results, which later proved that the hypothesis proposed before was correct. The results showed an expected time increase interval concerning the appropriate process ranging from 13:64 to 18:77 minutes. This as a result of the implementation of some convenient activities and procedures to handle the waste obtained from the disposal of the batteries. Considering the above, researchers expect a decrease in the impact of the high pollution index caused in the post-consumption of these accumulators. The new proposed process is carried out using techniques and methods based on safety for those who carry out the activity and for the environment in general. Table 3 shows the time obtained in the simulation of both the current and the proposed processes, based on confidence intervals, which correspond to the post-consumption treatment of a battery.

Table 3. Time interval difference between both processes

\begin{tabular}{ccc}
\hline $\begin{array}{c}\text { Current time } \\
\text { interval when } \\
\text { recycling a } \\
\text { battery } \\
(\mathbf{m i n})\end{array}$ & $\begin{array}{c}\text { Time interval of the } \\
\text { proposed process when } \\
\text { recycling a battery } \\
\text { (min) }\end{array}$ & $\begin{array}{c}\text { Time } \\
\text { interval } \\
\text { difference } \\
\text { (min) }\end{array}$ \\
\hline $9,48-9,94$ & $23,12-28,71$ & $13,64-$ \\
& & 18,77 \\
\hline
\end{tabular}

\section{Discussions}

Having the simulation of the process, the EIA, and the categorization of the most critical environmental factors for each stage, the impacts were classified according to their importance range, based on the color palette proposed by the methodology ${ }^{(13)}$ (some of these findings were already presented in Table 2).

- Compatible: 19 impacts out of 98 assessed were obtained, with a $19.2 \%$ percentage. The number of compatible effects is low. The process does not generate low contamination. 


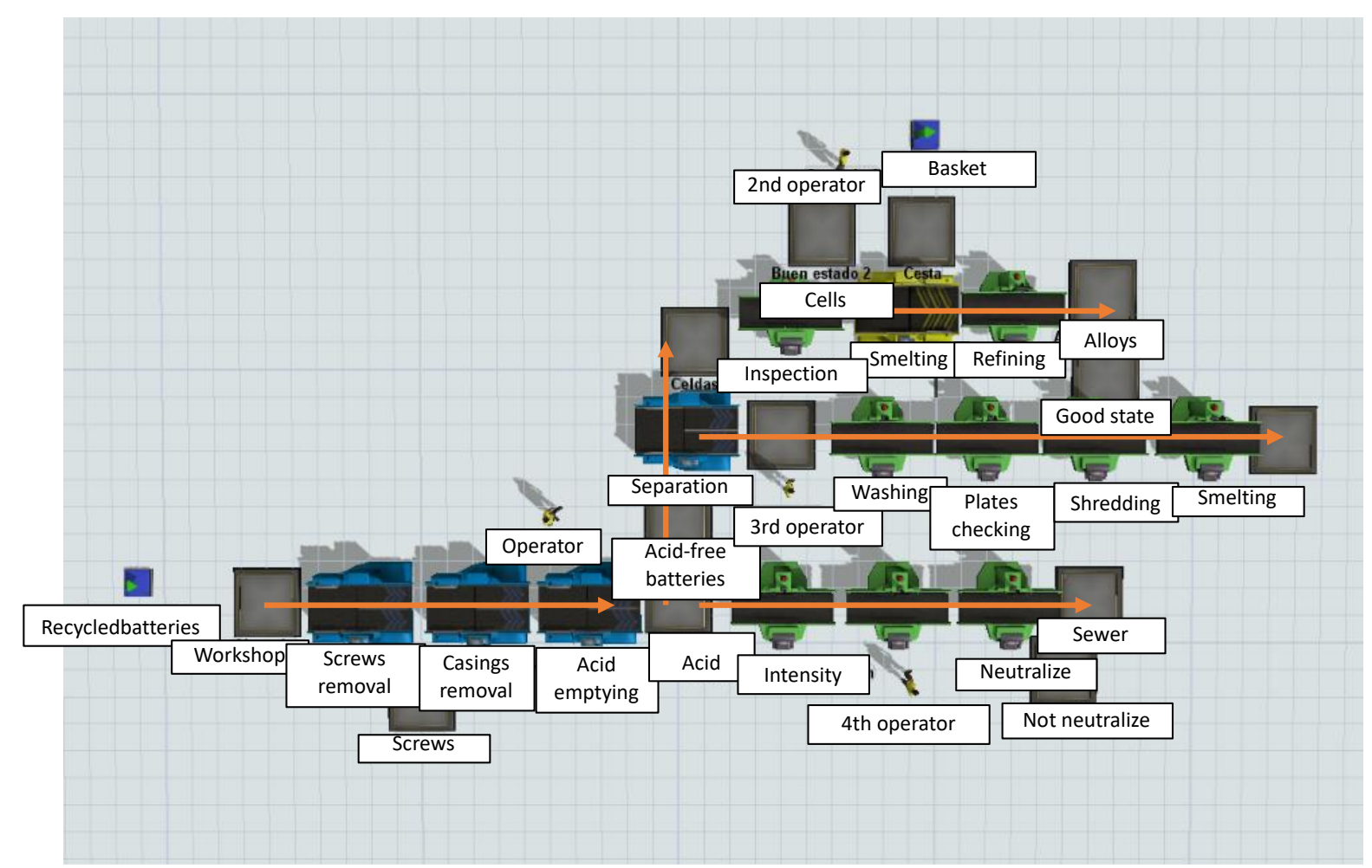

Figure 7. Model for the proposed final disposal process of lead-acid batteries

- Moderate: 50 impacts out of 98 assessed were obtained, with a $51 \%$ percentage. It is a very high rate of moderate effects. However, they can be controlled, which would allow the affected aspects to be recovered in the medium term if control and prevention measures are applied.

- Critical: 24 impacts out of 98 assessed were obtained, with a $24.4 \%$ percentage. There are many critical effects since many sources of contamination are generated during the process. However, the consequences may be reversible in the medium term.

- Severe: Four impacts out of 98 assessed were obtained, with a $4.1 \%$ percentage. There is a low number of severe effects.

Practices from this process generate different sources of contamination, especially in the stages of the electrolytes release, incineration, and lead smelting.

By analyzing results from the simulation of the mitigation proposal, it was possible to confirm that the elements included in the proposal are related to the pollution reduction indexes obtained in the assessment phase, which helps to reduce the severe and critical impacts that generate the most significant adverse effect on the environment. The feedback obtained from the target population facilitated dimensioning the problem and understanding how culture has a direct influence on the ability to generate changes in social processes and activities. The results obtained from the simulation of both models (conceptual and proposed) demonstrate that the time frame of the battery recycling process increases when applying the treatment techniques. However, these techniques are meant to reduce the negative impact generated in the soil and water by lead-batteries.

The mitigation of impacts would lead to a much more adequate preliminary treatment of waste in the short-term. In the medium and long-term, it would help to develop in people a culture of interest in the subject, prioritizing environmental and health issues over those associated with the 
economy. It is also expected that by adding the new procedures in the final disposal process, the efficiency in the lead, plastic, and acid recovery will increase since there is now specific machinery to carry out these procedures, eliminating the inaccuracy that can occur due to human factors.

\section{Conclusions}

The environmental impact mitigation has become a mandatory process to guarantee the sustainable development of the planet and future generations. Therefore, researchers built a proposal to mitigate the environmental impact that the batteries recycling process generates, given its global supply and demand. It was possible to find out that this process is carried out manually without safety control measures for human health and the environment. From the evaluation of impacts that were carried out for each stage of the recycling process, researchers used the Vicente Conesa method, discovering that indexes that generate a higher impact and that are classified as severe or critical are those produced by the electrolyte treatment and the plastic and lead recovery.

Researchers developed an explanatory booklet to provide some guidelines when carrying out the process. Through interviews and observation of the process, the elements that should be included in the booklet were analyzed, mainly oriented to an ideal way of developing the process. It is necessary to bring up the fact that the interviewed operators expressed the importance of reducing the impact despite the difficulties that they experience because they cannot afford some relevant requirements for the ideal process. Subsequently, the researchers compared the current and the proposed processes by simulating them in the FlexSim software. It was determined that there is an increase in the time interval of the proposed process compared to the current one due to the implementation of stages such as neutralization of sulfuric acid, lead refining, and plastic recycling, reducing the environmental impact.

It is noteworthy that the project has a social and environmental emphasis since taking care of the environment, and human health must be held as a responsibility. The objective of the proposal does not lie in financial aspects; instead, this process serves as a baseline for future research since it is a little-explored subject; therefore, it is left in consideration to be improved and potentiated in such an extent that it can generate a real impact in the way in which the disposal stage of the batteries is carried out.

\section{Acknowledgements}

This article was developed as a project of the GIGIA Research Group (Research Group in Industrial and Administrative Management) of the Manuela Beltrán University.

\section{Funding Statement}

The author(s) received no specific funding for this work.

\section{References}

(1) Sanmiguel-Torres JX, Guerrero-Carrera SR. Validación del método para determinar $\mathrm{Pb}, \mathrm{Cd}$, Ni por espectrometría de absorción atómica de llama en agua y suelo [dissertation]. Riobamba: Escuela Superior Politécnica de Chimborazo; 2017.

(2) Reciclaje de baterías de plomo-ácido usadas: consideraciones sanitarias [Internet]. Ginebra: World Health Organization (WHO); 2017. Available from:https://apps.who.int/iris/handle/106 65/259445.

(3) Gómez-Yepes ME, Cremades L V. Estudio del Manejo del Plomo en Establecimientos de Tipografia, 
Reconstruccion de Baterias y

Recicladores de Chatarra en el Departamento del Quindío, Colombia. Cienc Trab. 2013;15(46):7-11.

Macías-Troncoso M, Jara-Nivelo V. Proyecto de viabilidad técnica y ambiental de la gestión del reciclaje y la disposición final de las baterías de plomo-ácido de 12 voltios en Guayaquil [dissertation]. Guayaquil: Universidad de Guayaquil; 2011.

Análisis del sector y del mercado: selección mínima cuantia. Bogotá, Colombia: Fiscalía General de la Nación; 2016. Report No.: FGN-0122016.

(6) Sánchez EJC, Lucero J, Guzman A, Rocha J, Espinoza L. Review of the state of the art of batteries in automotive applications. Enfoque. 2018; 9 (1): 16676.https://doi.org/10.29019/enfoqueute.v 9n1.202.

(7) CCA - Comisión para la Cooperación Ambiental. Manejo ambientalmente adecuado de baterías de plomo ácido usadas en América del Norte: directrices técnicas. Montreal, Canada; 2016.

(8) Montoya NPM, Casas PA, Wandurraga CC. Plomo, cromo III y cromo VI y sus efectos sobre la salud humana. Cienc y
Tecnol para la salud Vis y Ocul. 2010; 8(1): 77-88.

Ariño-Castellano M. Sistema de Costes de una planta de Reciclaje de Baterías Plomo-Ácido [dissertation] Barcelona, España: Universitat de Vic; 2016.

(10) Cordero-Tapia A. Análisis del impacto ambiental producido por las baterías de plomo y su factibilidad de reciclaje para la ciudad de Cuenca [dissertation] Cuencia, Ecuador: Universidad del Azuay; 2012.

(11) Uiz-Olivares A, González-Chávez MC., Carrillo-González R, Reyes-Ramos M, Suarez Espinosa J. Dendrorremediación de Suelos Severamente Contaminados con Residuos del Reciclaje de Baterías Ácidas de Plomo. Agroproductividad. 2016; 9 (11-B): 68-9.

(12) Romero-Pavez MA. Estudio de la contaminación por plomo en suelos de una planta de reciclaje de baterías cerrada en Freire, IX Región [dissertation] Santiago, Chile: Universidad de Chile; 2017.

Fernández-Vítora VC. Guía metodológica para la evaluación del impacto ambiental. Mundi-Prensa Libros; 2009. 